\title{
WIND ENERGY CONVERSION SYSTEM BASED ON DFIG WITH THREE-PHASE SERIES GRID SIDE CONVERTER AND SINGLE DC-LINK
}

\author{
Ítalo A. Cavalcanti de Oliveira ${ }^{1}$, Cursino Brandao Jacobina ${ }^{2}$, Nady Rocha $^{3}$ \\ ${ }^{1}$ Post-Graduate Program in Electrical Engineering (PPgEE) - Federal University of Campina Grande (UFCG), Campina Grande \\ - Paraíba, Brazil \\ ${ }^{2}$ Electrical Engineering Department (DEE) - Federal University of Campina Grande (UFCG), Campina Grande - Paraíba, Brazil \\ ${ }^{3}$ Electrical Engineering Department (DEE) - Federal University of Paraíba (UFPB), João Pessoa - Paraíba, Brazil \\ e-mail: italo.oliveira@cear.ufpb.br, jacobina@dee.ufcg.edu.br, nadyrocha@cear.ufpb.br
}

\begin{abstract}
In this paper, a wind energy conversion system based on doubly-fed induction generator with an additional series grid side converter without transformer is proposed. Stator voltages may be compensated by series grid side converter under distorted and unbalanced grid voltage sags, thus avoiding over-current in the rotor, overvoltage in the dc-link, double-frequency oscillations in the electromagnetic torque, and rotor over-speed. Moreover, the control strategy of the proposed system allows reactive power to be injected during voltage sags. Simulation and experimental results are presented to evaluate the proposed system.
\end{abstract}

Keywords - Additional Series Converter, DFIG, Grid Voltage Disturbances, Transformerless, Wind Energy Conversion System.

\section{NOMENCLATURE}

DFIG Doubly-fed induction generator.

DSOGI Dual second order generalized integrator.

DSP Digital signal processor.

$D V R \quad$ Dynamic voltage restorer.

GSC Grid side converter.

LVRT Low voltage ride-through.

$P I \quad$ Proportional integral controller.

PLL Phase-locked loop.

$P M S G \quad$ Permanent magnet synchronous generator.

rms Root mean square.

RSC Rotor side converter.

SGSC Series grid side converter.

VOC Voltage-oriented control.

WECS Wind energy conversion systems.

$L_{p} \quad$ Inductor of the GSC filter.

$r_{p} \quad$ Resistance of the inductor $L_{p}$.

$l_{p} \quad$ Inductance of the inductor $L_{p}$.

$e_{g} \quad$ Grid voltage.

$v_{p} \quad$ Grid side converter's voltage.

$v_{t} \quad$ Series grid side converter's voltage.

$i_{g} \quad$ Grid current.

$i_{p} \quad$ Parallel current.

$\bar{x}_{s} \quad$ Vector of the stator variables.

$\bar{x}_{r} \quad$ Vector of the rotor variables.

Manuscript received 12/02/2020; first revision 03/12/2021; accepted for publication 04/20/2021, by recommendation of Editor Demercil de Souza Oliveira Jr. http://dx.doi.org/10.18618/REP.2021.2.0067

$\begin{array}{ll}v_{s} & \text { Stator voltage. } \\ v_{r} & \text { Rotor voltage. } \\ i_{s} & \text { Stator current. } \\ i_{r} & \text { Rotor current. } \\ \lambda_{s} & \text { Stator flux. } \\ \lambda_{r} & \text { Rotor flux. } \\ r_{s} & \text { Stator resistance. } \\ r_{r} & \text { Rotor resistance. } \\ l_{s} & \text { Stator inductance. } \\ l_{r} & \text { Rotor inductance. } \\ l_{m} & \text { Mutual inductance. } \\ c_{e} & \text { Electromagnetic torque. } \\ c_{m} & \text { Mechanical torque. } \\ J & \text { Moment of inertia. } \\ F & \text { Coefficient of friction. } \\ P & \text { Number of pole pairs. } \\ P_{g} & \text { Grid active power. } \\ Q_{g} & \text { Grid reactive power. } \\ P_{s} & \text { Stator active power. } \\ Q_{s} & \text { Stator reactive power. }\end{array}$

\section{INTRODUCTION}

Wind energy is one of the most promising among many types of renewable energy sources, with increasing participation in the global electric matrix [1]-[3]. Most WECS are variable speed systems that use two main types of generators [4]-[6]: PMSG and DFIG. Among variable speed wind energy conversion systems, DFIG is the most widely used generator [6], [7] due to, in addition to other characteristics, advantages such as: controllable power factor, improvement of the system efficiency, durability, reduced mechanical stress, lower cost, reduced power converter rating (typically $30 \%$ of the generator rating), variable speed control, and four-quadrant active and reactive power control [5], [8][11].

However, since the stator windings of the DFIG are directly connected to the grid, these wind energy conversion systems based on DFIG are especially susceptible to grid voltage disturbances. In past years, disconnection of wind energy conversion systems was a possible solution to protect the wind system [12]-[14], however, with increasing wind power's participation in the power grid, most grid codes require that wind energy conversion systems must remain connected when a grid fault occurs [7], [11], [15]-[19]. According to these grid codes, the wind energy conversion systems must be able to withstand voltage sags, i.e., the system must have LVRT 
capability, and must act with reactive power compensation in order to collaborate in the grid voltage recovery [7], [11], [15][26]. In addition, some grid codes require that wind energy conversion systems remain connected even in the event of $2 \%$ steady-state and $4 \%$ short term voltage imbalances [12], [27].

In Brazil, the grid connection code requires that wind farm remains connected according to the LVRT capability curve presented in Figure 1 [25]. According to the LVRT capability curve, the wind energy conversion systems must be able to withstand voltage sags between $10 \%$ and $15 \%$ for 5 seconds. Furthermore, from Figure 1, the system must withstand during 0.5 milliseconds for a voltage sag of $80 \%$. This grid connection code also requires the WECS to supply reactive currents to the grid proportional to the voltage sag.

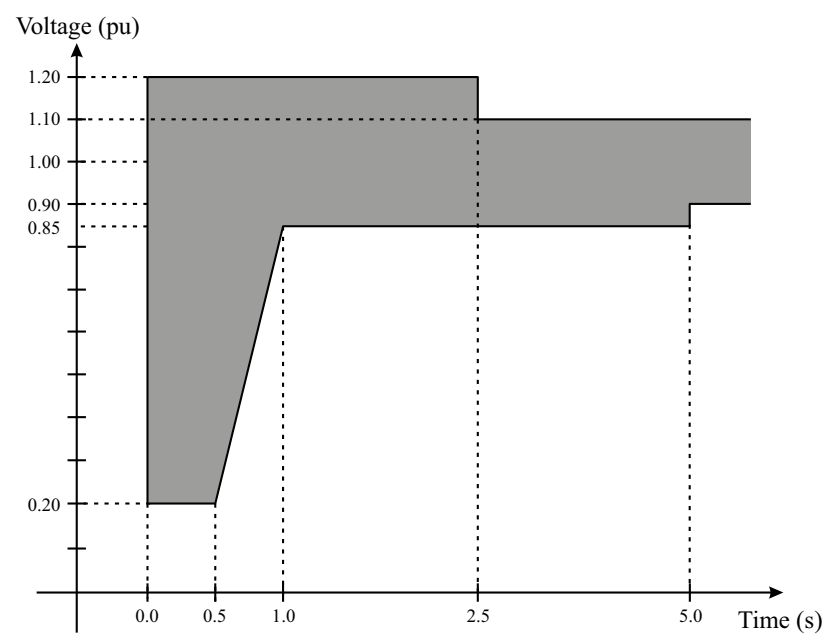

Fig. 1. Brazilian low voltage ride-through capability curve [25].

To keep the generator connected to the grid under non-ideal conditions, it is necessary to mitigate the negative effects on the generation system under such conditions [28]. Several solutions have been proposed to reduce the impacts on the generator, such as introducing a crowbar in the rotor circuit of DFIG [26], [29], [30]; DVR [31]; modified control strategies [19], [32]-[34]; or additional converters at grid side [11], [13], [15]-[18], [35].

Solutions like the crowbar in the rotor circuit, DVR, and temporary stator disconnection do not have a good performance during a deep unbalanced voltage sag and they can cause large transient spikes in the generator currents and torque [17], [20]. Furthermore, DVR system requires protection circuits with by-pass switches to prevent overload in the converters. Such DVR system features make this solution unattractive economically [13].

Despite obtaining satisfactory responses to generalized voltage sags, the use of modified control strategies results in a compromised solution between the reduction of doublefrequency oscillations in electromagnetic torque and the obtaining balanced stator and rotor currents [13], [15], [17], [20], [35]. Generally, control strategies choose to suppress the electromagnetic torque oscillations in detriment of balanced stator currents [35]. Thus, the unequal heating of stator windings caused by this imbalance in the stator currents will degrade the insulation of the stator coils and reduce their life span [32]-[34], [36]-[38].
Replacing the conventional parallel connection of the grid side converter by a series connection through series injection transformers configures as another solution to keep the WECS connected to the power grid during symmetrical or asymmetrical faults. This solution was investigated in [22], [39]-[42].

In [40]-[42], the series converter composed of three singlephase converters presented in [39] and [22] is replaced by a conventional three-phase converter, thus allowing the use of a simpler and unified control strategy. Despite the grid voltage imbalances compensation, the control strategy presented in [40] does not limit the fault currents and does not completely eliminate the oscillations in the active and reactive stator powers and in the electromagnetic torque. In [41] is proposed a control method that reduces the grid voltage unbalance and the oscillations of the electromagnetic torque by injecting negative sequence components of the stator voltage and rotor current, respectively. Although it achieves the proposed objectives, the method presented in this paper may not protect the electrical components of the DFIG by injecting unbalanced currents into the stator and rotor windings.

The control strategies presented in [22], [39]-[41] do not act on voltage sag compensation, not using the total capacity of the series converter. Differently, the control strategy employed in [42] acts on the grid voltage sag compensation during grid faults. However, despite obtaining stator voltage compensation, the overall system dynamics is worse than the conventional system dynamics.

With an additional series converter at grid side, known as SGSC, it is possible compensate grid voltage disturbances (such as distortions and voltage imbalances), thus compensating the stator voltage, reducing doublefrequency oscillations in the electromagnetic torque, active and reactive power and obtaining compensated and sinusoidal stator currents simultaneously. This would further improve the LVRT capability of wind energy conversion systems based on DFIG. Furthermore, as demonstrated in [13], [35], the power flowing through the series grid side converter is proportional to the voltage sag, i.e., the series grid side converter rating needed to cope with a $10 \%$ voltage sag is approximately $10 \%$ of DFIG-based system rating and the total power losses of the series grid side converter (including series injection transformer losses) is around 2\% of DFIG-based system rating. However, this scenario only occurs if the generator power is maintained at the pre-fault value. Some connection codes, such as the Brazilian one, do not require for severe faults of $80-90 \%$ profundity that the active power be maintained at the pre-fault value. With this, the converter will handle a portion of the power even for severe sags.

There are mainly two ways to connect the additional series converter, one through series injection transformers [Figures 2.a and 2.b] and another using the open-end winding of the DFIG [Figure 2.c]. In [13], [17], [35] are presented systems in which the additional series converter is connected between the GSC connection point and the DFIG stator terminals [Figure 2.a], while in [11], [16], [18] the additional series converter is connected before the grid side converter connection point. Presented results and performance of these topologies are similar despite the differences between the connection types. 
In [15], Flannery and Venkataramanan also present topologies in which the additional series converter is connected in the DFIG stator open-end windings, as shown in Figure 2.c.

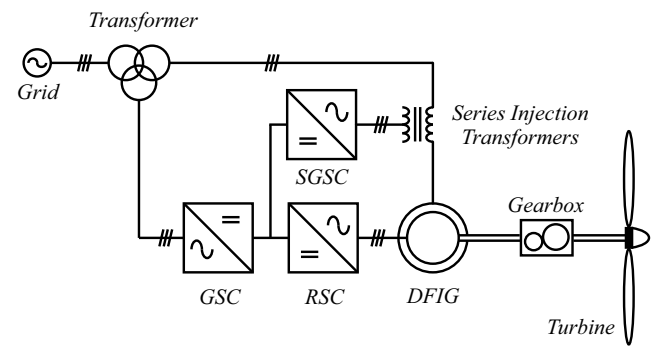

(a)

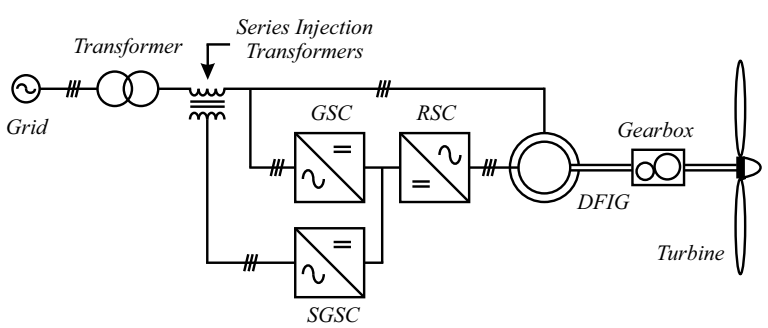

(b)

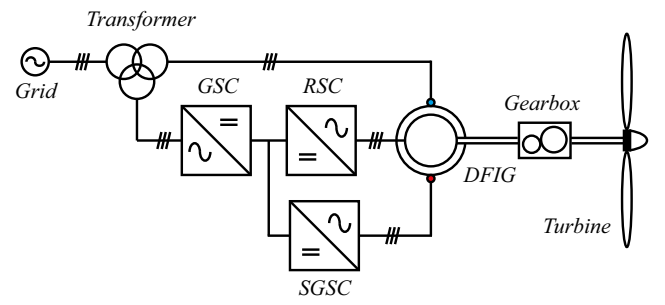

(c)

Fig. 2. Connection types for additional series grid side converter. (a) Connection between the grid side converter connection point and stator terminals. (b) Connection before the grid side converter connection point. (c) Connection with stator open-end windings.

In [18] is proposed a DFIG integration scheme with an additional series converter at the stator DFIG terminals acting as a DVR to improve the LVRT capability. According to [18], the use of series converter could result in additional benefits, such as active series filtering, reactive power compensation, and electronic isolation. With compensation control proposed in [18], over-current and over-voltage in the rotor windings are significantly reduced. However, in addition to using series injection transformers (increasing the losses and complexity of the system), the proposed solution only acts on the reduction of the over-current and over-voltage due to the grid fault. Thus, oscillations in rotor speed are not eliminated while symmetric fault occurs and the dc-link voltage is not controlled during the faults studied in [18], presenting high oscillations during an asymmetric fault.

In [43], [44], a system operating with two dc-link, one for the back-to-back converter and another for the additional series converter operating with floating capacitors, was proposed. However, the additional series converter in such works or only assists the system performances during several grid voltage disturbances or only reduces harmonic distortions at DFIG stator terminals without grid voltage sag or swell compensation.
In this paper, a wind energy conversion system based on DFIG with series grid side converter is proposed, i.e., a standard two-level voltage source inverter, fed Open-End Winding DFIG with single dc-link voltage and without a transformer, as shown in Figure 3. The proposed system without series injection transformers has less complexity, lower cost, and reduced losses compared to the conventional system with additional series converter [45]. Moreover, the proposed system also compensates the voltages in the stator terminals of DFIG even during distorted and unbalanced grid voltage conditions, thus improving the LVRT. In addition to the series grid side converter, the proposed system is composed of a grid side converter, which ensures a regulated dc-link voltage and maintains a high grid power factor (through the grid current control), and a rotor side converter, which regulates the stator active and reactive power through a voltage-oriented control.

Compared to the conventional system, the proposed system does not require the use of any transformer (series injection transformer or a parallel transformer for connecting the GSC) and reduces the circulation current without using bulky components, resulting in a system with lower cost and weight and with high LVRT capacity.

The proposed system in this work was previously analyzed in [46] for a static voltage sag condition and in [47] for series active filter applications. In [46] and [47], the experimental results were obtained without DFIG and only validated the GSC and SGSC controls. In this work, simulation results for a dynamic voltage sag condition (i.e., with inception and clearance of the voltage sag) with harmonic distortions and imbalances are presented and analyzed. The work also presents more complete experimental results for a grid voltage sag, demonstrating the compensation capacity of the proposed system and validating the controls employed in all three converters. In addition, the control strategy proposed for SGSC in this work is able to deal with voltage imbalances and harmonic distortions simultaneously, unlike the controls proposed in [46] and [47]. The present work also brings a detailed controller design to obtain the parameters of the controllers employed in the system.

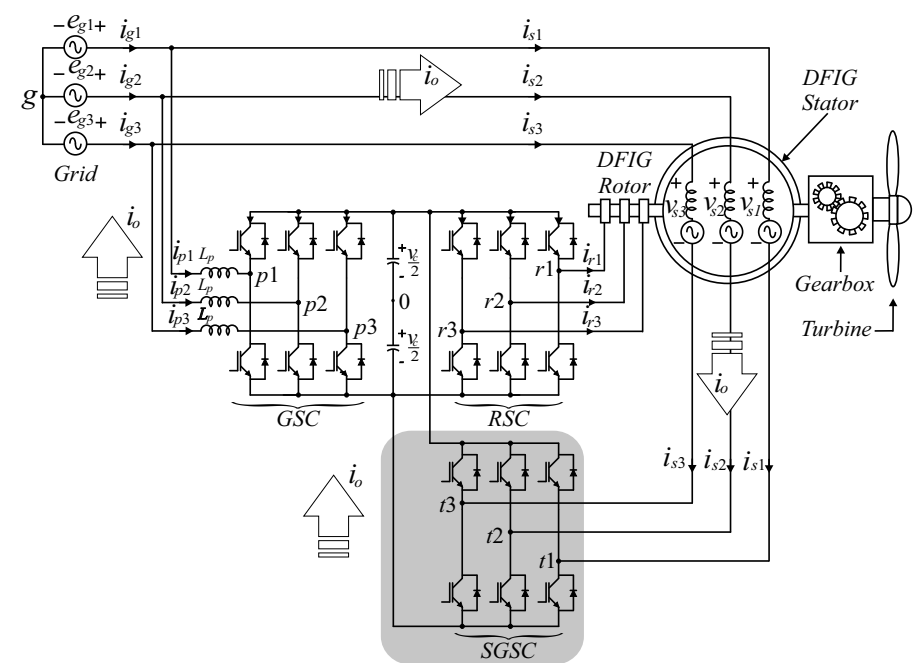

Fig. 3. Proposed DFIG system with additional series grid side converter without transformers. 
Since the series grid side converter is connected directly to the terminals of DFIG without any transformer [unlike Figure 2.c], there will be a circulating current between the grid side converter and series grid side converter that must be suppressed by the control system (Figure 3 ).

To reduce the circulating current without adding bulky components (as common-mode inductors to increase the zero sequence impedance [48], [49]), circulating current control strategies are presented as a simple and effective solution. Differently of previous works, which need a transformer for grid connection and do not discuss the circulating current issue, in this paper a control to reduce the circulating current is proposed and analyzed.

The control strategy of the proposed system ensures i) stator active and reactive power control, ii) compensated and sinusoidal voltages in the stator of DFIG during distorted grid voltage sag conditions, and iii) null circulating current between GSC and SGSC.

This work is organized as follows: in Section II the system models are described, while the control strategies are presented and analyzed in Section III. Simulation and experimental results are presented in Section IV and Section $\mathrm{V}$, respectively, to validate the proposed system.

\section{SYSTEM MODELS}

\section{A. SGSC and GSC Models}

From the proposed system presented in Figure 3, it is possible to obtain the series grid side converter and grid side converter models as follows [47], [50]:

$$
\begin{aligned}
e_{g k} & =v_{s k}+v_{t k} \\
e_{g k} & =r_{p} i_{p k}+l_{p} \frac{d i_{p k}}{d t}+v_{p k} \\
i_{g k} & =i_{s k}+i_{p k} \\
v_{g 0} & =\frac{1}{6}\left(\sum_{k=1}^{3} v_{t k 0}+\sum_{k=1}^{3} v_{p k 0}\right) \\
v_{t k} & =v_{t k 0}-v_{g 0} \\
v_{p k} & =v_{p k 0}-v_{g 0},
\end{aligned}
$$

in which $k=1,2,3 ; r_{p}$ and $l_{p}$ are the resistance and the inductance of the inductor $L_{p}$, respectively; $e_{g k}$ are the grid voltages; $v_{s k}$ are the DFIG stator voltages; $v_{t k}$ are the voltages provided by the series converter; $v_{p k}$ are the voltages provided by the grid side converter; $v_{p k 0}$ are the pole voltages of the grid side converter; $v_{t k 0}$ are the pole voltages of the series converter; $v_{g 0}$ is the voltage between of central point of the grid ('g') and the central point of dc-link ('0'); $i_{g k}$ are the grid currents; $i_{s k}$ are the DFIG stator currents and $i_{p k}$ are the parallel currents through GSC.

In this configuration there is a circulating loop between SGSC and GSC, in which the following equations are derived [46], [47]:

$$
v_{t k}^{\prime}-v_{p k}^{\prime}=0
$$

in which

$$
\begin{aligned}
v_{t k}^{\prime} & =v_{s k}+v_{t k 0} \\
v_{p k}^{\prime} & =v_{p k 0}+r_{p} i_{p k}+l_{p} \frac{d i_{p k}}{d t} .
\end{aligned}
$$

From (7) to (9) it is possible to define the voltage $v_{o}$ as follows:

$$
v_{o}=\sum_{k=1}^{3} v_{p k 0}-\sum_{k=1}^{3} v_{t k 0} .
$$

The circulating current of the SGSC $\left(i_{s o}\right)$ and of the GSC $\left(i_{p o}\right)$ are defined by (Figure 3$)$ :

$$
i_{s o}=\sum_{k=1}^{3} i_{s k} \text { and } i_{p o}=\sum_{k=1}^{3} i_{p k} .
$$

Therefore, the circulating current between the converters can be written as a function of a single circulating current, i.e.:

$$
i_{o}=i_{s o}=-i_{p o}
$$

Replacing (11) and (12) in (10), and taking into account that the stator voltages are balanced (i.e., $\sum_{k=1}^{3} v_{s k}=0$ ), the voltage $v_{o}$ can be rewritten as a function of the circulating current:

$$
v_{o}=r_{p} i_{o}+l_{p} \frac{d i_{o}}{d t}
$$

\section{B. DFIG Model}

The vector model in the synchronous stator voltage frame (superscript ' $e$ ') of DFIG is [51], [52]:

$$
\begin{aligned}
\bar{v}_{s}^{e} & =r_{s} \bar{i}_{s}^{e}+\frac{d}{d t} \bar{\lambda}_{s}^{e}+j \omega_{s} \bar{\lambda}_{s}^{e} \\
\bar{v}_{r}^{e} & =r_{r} \bar{i}_{r}^{e}+\frac{d}{d t} \bar{\lambda}_{r}^{e}+j\left(\omega_{s}-\omega_{r}\right) \bar{\lambda}_{r}^{e} \\
\bar{\lambda}_{s}^{e} & =l_{s} \bar{i}_{s}^{e}+l_{m} \bar{i}_{r}^{e} \\
\bar{\lambda}_{r}^{e} & =l_{m} \bar{i}_{s}^{e}+l_{r} \bar{i}_{r}^{e} \\
c_{e} & =P l_{m} \mathfrak{I}\left(\bar{i}_{s}^{e} \bar{i}_{r}^{e *}\right) \\
P\left(c_{e}-c_{m}\right) & =J \frac{d \omega_{r}}{d t}+F \omega_{r},
\end{aligned}
$$

where $\bar{x}_{s}^{e}=\frac{1}{\sqrt{2}}\left(x_{s d}^{e}+j x_{s q}^{e}\right)$ is the generic vector of the stator variables, i.e., voltage $\left(\bar{v}_{s}^{e}\right)$, flux $\left(\bar{\lambda}_{s}^{e}\right)$, and current $\left(\bar{i}_{s}^{e}\right) ; \bar{x}_{r}^{e}=$ $\frac{1}{\sqrt{2}}\left(x_{r d}^{e}+j x_{r q}^{e}\right)$ is the generic vector of the rotor variables, i.e., voltage $\left(\bar{v}_{r}^{e}\right)$, flux $\left(\bar{\lambda}_{r}^{e}\right)$, and current $\left(\bar{i}_{r}^{e}\right) ; r_{s}$ and $r_{r}$ are the stator and rotor resistances, respectively; $l_{s}$ and $l_{r}$ are the stator and rotor inductances, respectively; $l_{m}$ is the mutual inductance between the windings of the stator and rotor; $\omega_{s}$ is the frequency of the stator voltage; $\omega_{r}$ is the electric rotor speed; $c_{e}$ is the electromagnetic torque; $c_{m}$ is the mechanical torque; $J$ is the moment of inertia; $F$ is the coefficient of friction; $P$ is the number of pole pairs of the machine; $\mathfrak{I}(z)$ is the imaginary part of $z$, and the superscript ' $*$ ' represents the conjugate complex of the term. 


\section{CONTROL STRATEGIES}

Figure 4 shows the control diagram used in the proposed system. The control system consists of two control loops, one for SGSC and GSC and another for RSC. The grid side converter control has the function of controlling the dc-link voltage and the grid reactive power; while the series grid side converter control ensures compensated and sinusoidal stator voltage even during distorted voltage sag events. Furthermore, both GSC and SGSC control system have the function to keep null circulating current. Meanwhile, the rotor side converter control acts in controlling the rotor speed and regulates the stator active and reactive powers. The control loops will be detailed in the following sections.

\section{A. Control of GSC}

According to [53], the voltage over the dc link can be expressed as a function of the capacitors' power. Also considering that the power of the grid is proportional to the power of the DFIG and the converters, the voltage of the dc link will be:

$$
\frac{d v_{c}^{2}}{d t}=-\frac{2 P_{g}}{C}
$$

in which $v_{c}$ stands for the dc-link voltage, $P_{g}$ is grid active power, and $C$ is the dc-link capacitance.

Expressing the grid active power in the synchronous reference frame, in which $e_{g d}^{e}=0$ and $e_{g q}^{e}=e_{g}$, the dc-link voltage can be rewritten as a function of the $q$-axis grid current, i.e.:

$$
\frac{d v_{c}^{2}}{d t}=-\frac{2\left(e_{g} i_{g q}^{e}\right)}{C}
$$

while the grid reactive power $\left(Q_{g}\right)$ is a proportional to the $q$ axis grid current:

$$
Q_{g}=e_{g} i_{g d}^{e}
$$

The control loop of SGSC and GSC is presented in Figure 4. The dc-link voltage $v_{c}$ is regulated by a PI controller providing the reference of the $q$-axis grid current in synchronous reference frame $\left(i_{g q}^{e *}\right)$. Similarly, the grid reactive power $Q_{g}$ is regulated by a PI controller that provides the reference of the $d$-axis grid current in the synchronous reference frame $\left(i_{g d}^{e *}\right)$. These references are, then, transformed to the stationary reference frame through the $e^{j \theta}$ block. To change the reference frame of the grid currents, the $e^{j \theta}$ block uses the estimated angle of the grid voltages $\left(\theta_{g}\right)$. Since the grid voltages are disturbed (with harmonic distortions and voltage imbalances), the phases of grid voltages are obtained by a DSOGI-PLL described in [54]. The $d q$-axes grid currents are regulated by resonant type controllers [55] represented by $\left(P R_{i g}\right.$ block), thus providing the $d q$-axes reference voltages $\left(v_{p d}^{s *}\right.$ and $\left.v_{p q}^{s *}\right)$. Then, the reference voltages are transformed into natural base by the $d q / 123$ block, resulting in the reference GSC voltages $v_{p 1}$ and $v_{p 2}$.

\section{B. Control of SGSC}

The stator voltages $\left(v_{s 1}\right.$ and $\left.v_{s 2}\right)$ are also controlled by resonant controllers $\left(P R_{v s}\right.$ block) and the output signals are added to the harmonic reference components $\left(e_{h r 1}^{*}\right.$ and $\left.e_{h r 2}^{*}\right)$, resulting in the reference voltages $\left(v_{t 1}^{*}\right.$ and $\left.v_{t 2}^{*}\right)$ that regulates the series converter to reduce and compensate imbalances and harmonic distortion at the DFIG stator terminals.

The harmonic reference components are extracted by subtracting the grid voltages $\left(e_{g 1}\right.$ and $\left.e_{g 2}\right)$ by their respective fundamental voltages $\left(e_{g f 1}\right.$ and $\left.e_{g f 2}\right)$. The fundamental components of the grid voltage are extracted by the DSOGI block (as shown in Figure 4). Once this block is able to extract the positive sequence components, it is also able to filter the fundamental components of the grid voltage.

The reference stator voltages $\left(v_{s 1}^{*}\right.$ and $\left.v_{s 2}^{*}\right)$ are obtained by the $G v s$ block. The $G v s$ block represents the product between the reference amplitude of the stator voltage $\left(V_{s}^{*}\right.$ set as the rated of the stator voltage) and sinusoidal signals, whose phases are the estimated phases from grid voltages (i.e., $\hat{\theta}_{g 1}$ and $\hat{\theta}_{g 2}$ ). In other words, the stator voltage and the grid voltage are synchronized. In this way, the series converter ensures balanced and sinusoidal voltages at the terminals of DFIG and eliminates critical problems that affect the DFIG during grid voltage disturbances.

\section{Control of Circulating Current}

The last control mash is based on a resonant controller ( $P R_{i o}$ block), which regulates the circulating current $i_{o}$ to zero, providing the reference circulating voltage $v_{o}^{*}$. Therefore, the reference voltages $v_{t 1}^{*}, v_{t 2}^{*}, v_{p 1}^{*}, v_{p 2}^{*}$, and $v_{o}^{*}$ are used to define the switch states of SGSC and GSC.

\section{Control of RSC}

As mentioned before, traditional vector control can be employed at the rotor side converter. Thus, in the rotor side converter control loop a VOC is employed, which performs stator active and reactive powers control [51], [52]. From the DFIG vector model in the synchronous stator voltage frame, in which $v_{s d}^{e}=0$ and $v_{s q}^{e}=v_{s}$, and neglecting resistive losses in the stator windings, the active and reactive powers $\left(P_{s}\right.$ and $Q_{s}$, respectively) can be written as a function of the rotor currents, such that:

$$
\begin{aligned}
P_{s} & =-\frac{l_{m}}{l_{s}} v_{s} i_{r q}^{e} \\
Q_{s} & =\frac{l_{m}}{l_{s}} v_{s}\left(\frac{v_{s}}{l_{m} \omega_{s}}-i_{r d}^{e}\right) .
\end{aligned}
$$

The reactive power can be controlled by $i_{r d}^{e}$ regardless of $i_{r q}^{e}$, thus featuring a fully decoupled control of stator active and reactive powers.

Then, making $Q_{s}^{*}=0$ to ensure a high power factor, the $d$ axis rotor reference current $\left(i_{r d}^{e *}\right)$ is determined by the output of a signal (see Figure 4). On the other hand, the $q$-axis rotor reference current $\left(i_{r q}^{e *}\right)$ is obtained from another PI controller $\left(P I_{p s}\right.$ block) that regulates stator active power. Also, reactive power can be injected into the power grid during voltage sags using the rotor side converter or grid side converter, thus acting in the power grid recovery.

The $d q$-axes rotor currents provide the reference rotor 


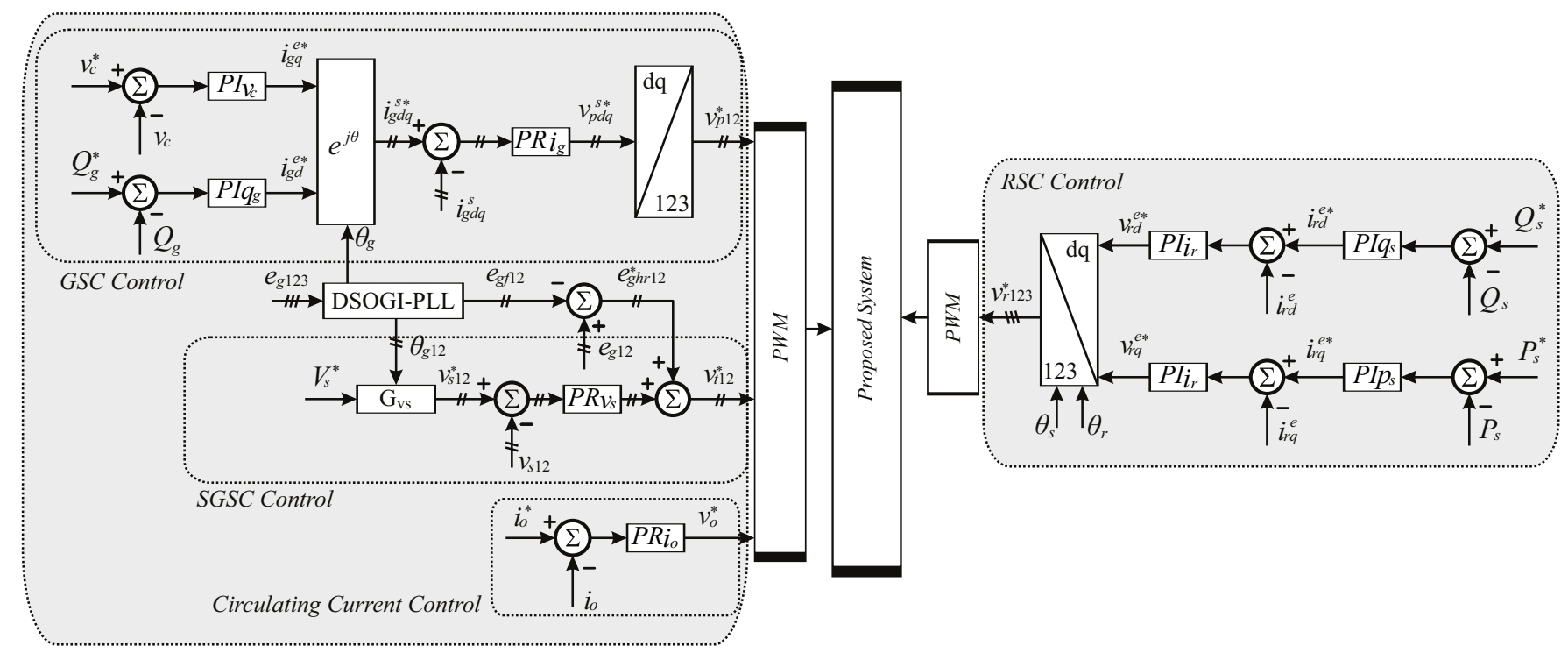

Fig. 4. Schematic of control for SGSC, GSC, and RSC.

voltages $v_{r d}^{e *}$ and $v_{r q}^{e *}$. Then, the reference voltages $v_{r 1}^{*}, v_{r 2}^{*}$, and $v_{r 3}^{*}$ are used to define the switch states of the rotor side converter, as shown in Figure 4.

\section{E. Controller Design}

The design of the controllers is performed using the gains tuning techniques presented in [53]. In this section, the design of the circulating current loop controller $\left(P R_{i o}\right)$ will be presented, while the gains of the other controllers can be similarly tuned.

From (13) it is possible to write the circulating current plant on terms of the Laplace operator $s$ :

$$
\frac{I_{o}(s)}{V_{o}(s)}=P_{i o}(s)=\frac{\frac{1}{l_{p}}}{s+\frac{r_{p}}{l_{p}}} .
$$

The block diagram of the circulating current control loop is shown in Fig 5, in which the resonant controller is approximated by a PI controller for purposes of calculating the proportional and integral gains, since the gains of a resonant controller can be adjusted similarly to a PI controller [56].

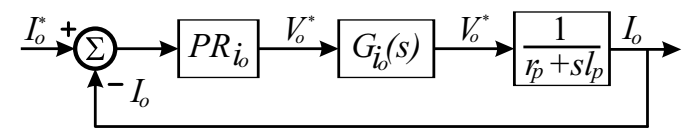

Fig. 5. Block diagram of the control loop of $i_{o}$.

In Figure 5, $K p_{i o}$ and $K i_{i o}$ are the proportional and integral gains, respectively. Thus using the pole-zero cancellation, i.e., $\frac{K i_{i o}}{K p_{i o}}=\frac{r_{p}}{l_{p}}$, the transfer function of open-loop is:

$$
G_{i o}(s)=\frac{K p_{i o}}{l_{p} s}\left(\frac{s+\frac{K i_{i o}}{K p_{i o}}}{s+\frac{r_{p}}{l_{p}}}\right)=\frac{K p_{i o}}{l_{p} s},
$$

From (26), the transfer function of closed-loop is:

$$
C_{i o}(s)=\frac{1}{\tau_{i o} s+1}
$$

where $\tau_{i o}=\frac{l_{p}}{K p_{i o}}$ is the time constant of the transfer function of the closed-loop system. The value of $\tau_{i o}$ is a design parameter that must be chosen according to the desired response speed for the closed-loop system [53]. Observe that:

$$
\begin{aligned}
K p_{i o} & =\frac{l_{p}}{\tau_{i o}} \\
K i_{i o} & =\frac{r_{p}}{\tau_{i o}} .
\end{aligned}
$$

To calculate the control gains, the speed response was $\tau_{i o}=$ $0.8 \mathrm{~ms}$

\section{PWM Strategies}

In this section, the PWM strategies of the GSC and SGSC are presented. The PWM strategy of the RSC is presented in [46], [47].

The reference pole voltages are determined by [47]:

$$
\begin{aligned}
v_{t 10}^{*} & =v_{t 1}^{*}+v_{x}^{*} \\
v_{t 20}^{*} & =v_{t 2}^{*}+v_{x}^{*} \\
v_{t 30}^{*} & =v_{t 3}^{*}-\frac{v_{o}^{*}}{2}+v_{x}^{*} \\
v_{p 10}^{*} & =v_{p 1}^{*}+v_{x}^{*} \\
v_{p 20}^{*} & =v_{p 2}^{*}+v_{x}^{*} \\
v_{p 30}^{*} & =v_{p 3}^{*}+\frac{v_{o}^{*}}{2}+v_{x}^{*} .
\end{aligned}
$$

The auxiliary voltage can be chosen arbitrarily since the maximum and minimum values of the pole voltages are respected. Thus:

$$
\begin{aligned}
& v_{x \max }^{*}=\frac{v_{c}^{*}}{2}-V_{x \max } \\
& v_{x \min }^{*}=-\frac{v_{c}^{*}}{2}-V_{x \min }
\end{aligned}
$$

where $V_{x \max }=\max \left\{v_{t 1}^{*}, v_{t 2}^{*}, v_{t 3}^{*}-\frac{v_{o}^{*}}{2}, v_{p 1}^{*}, v_{p 2}^{*}, v_{p 3}^{*}+\frac{v_{o}^{*}}{2}\right\}$ and 
$V_{x \min }=\min \left\{v_{t 1}^{*}, v_{t 2}^{*}, v_{t 3}^{*}-\frac{v_{o}^{*}}{2}, v_{p 1}^{*}, v_{p 2}^{*}, v_{p 3}^{*}+\frac{v_{o}^{*}}{2}\right\}$. Then, the auxiliary voltage $v_{x}^{*}$ can be writen by a factor $\mu_{x}$ with $0 \leq \mu_{x} \leq$ 1, thus:

$$
v_{x}^{*}=\mu_{x} v_{x \max }^{*}+\left(1-\mu_{x}\right) v_{x \min }^{*} .
$$

The switch states are defined by comparing the pole voltages with a high frequency triangular carrier PWM.

\section{SIMULATION RESULTS}

Two sets of simulation results are obtained. One set for an unbalanced voltage sag (Figures 6 to 8 ) and another for a three-phase voltage sag of $80 \%$ (Figures 9 to 11). In Both sets a fundamental grid voltage of $220 \mathrm{~V} \mathrm{rms}$ (phase voltage), a $650 \mathrm{~V}$ dc-link voltage, a dc-link capacitance of $100 \mu \mathrm{F}$, a stator active power of $-1.5 \mathrm{~kW}$, a rotor speed of $365 \mathrm{rad} / \mathrm{s}$, and an electromagnetic torque of $-2.7 \mathrm{Nm}$ were considered. The parameters of the DFIG utilized in the computational simulation are shown in Table I. Discrete controllers with a sampling frequency of $10 \mathrm{kHz}$ were used in the computational simulation and the values of the controllers gains are presented in Table II.

\section{A. Unbalanced Voltage Sag}

For the results with unbalanced voltage sag, a D-Type voltage sag [57] with a characteristic voltage of $80 \%$ of the rated voltage is applied at $t=0.1 \mathrm{~s}$ and cleared after $0.5 \mathrm{~s}$. During the sag event, the grid voltage also contains $5^{\text {th }}$ and $7^{\text {th }}$ harmonic components with amplitude approximately $9.65 \%$ and $3.20 \%$ of the fundamental amplitude, respectively.

\section{TABLE I}

\section{Specification of the DFIG Parameters.}

\begin{tabular}{cccc}
\hline Parameters & Values & Parameters & Values \\
\hline Rated power & $2 \mathrm{~kW}$ & Rotor inductance & $14.9 \mathrm{mH}$ \\
\hline Stator phase voltage & $220 \mathrm{~V}$ & Mutual inductance & $599.2 \mathrm{mH}$ \\
\hline Stator resistance & $3.0 \Omega$ & Number of poles & 2 \\
\hline Rotor resistance & $2.99 \Omega$ & Moment of inertia & $0.003 \mathrm{~kg} \cdot \mathrm{m}^{2}$ \\
\hline Stator inductance & $14.9 \mathrm{mH}$ & Stator/rotor turns ratio & 1 \\
\hline
\end{tabular}

TABLE II

Specification of the Controllers Gains.

\begin{tabular}{ccc}
\hline Controller & Proportional Gain $\left(K_{p}\right)$ & Integral Gain $\left(K_{i}\right)$ \\
\hline$P I_{v c}$ & 0.5 & 3 \\
\hline$P I_{q g}$ & $5 \times 10^{-4}$ & 0.3 \\
\hline$P R_{i g}$ & 60 & $4 \times 10^{3}$ \\
\hline$P R_{v s}$ & 0.01 & 200 \\
\hline$P R_{i o}$ & 10 & 625 \\
\hline$P I_{q s}$ & $1.4 \times 10^{-3}$ & 0.61 \\
\hline$P I_{p s}$ & $1.4 \times 10^{-3}$ & 0.61 \\
\hline$P I_{i r}$ & 642.82 & $6.52 \times 10^{4}$ \\
\hline
\end{tabular}

In Figures 6 to 8 are shown simulation results for an unbalanced voltage sag. Dynamic responses and a detail of the grid voltage sag inception are presented in Figure 6. The grid voltages are shown in Figure 6.a, while the stator voltages are presented in Figure 6.b. Notice that the series converter ensures sinusoidal and balanced stator voltages despite the unbalance and distortion of the grid voltage. The series voltage of the SGSC rises at the inception of the voltage sag to compensate the grid imbalances and distortions [Figure 6.c]. The inception and at the clearance of the voltage sag. Moreover, it is possible to note that the $5^{\text {th }}$ and $7^{\text {th }}$ harmonic components of the grid voltages are compensated at stator voltages. Thus, the SGSC control ensures sinusoidal and balanced voltages at the DFIG stator terminals.

In Figure 7.a is possible to note that the grid currents are sinusoidal and balanced before the entry of the voltage sag. However, with the sag at $t=0.1 \mathrm{~s}$, the grid currents become unbalanced and distorted. The control carried out by the GSC does not provide for the compensation of these disturbances in the grid currents, such as reduction of harmonic content and negative sequence components. Although the disturbances remain present in the grid currents, the GSC maintains the amplitude of the currents under control and guarantees the stability of the system. The stator currents, on the other hand, are sinusoidal and balanced, as shown in Figure 7.b, since the series converter maintains balanced and sinusoidal voltages at stator terminals. The $d q$-axes rotor currents in the synchronous reference frame are presented in Figure 7.c (top). It can be noted that the RSC control loop regulates the rotor currents to their respective reference value even during the voltage sag.

In Figure 7.c (bottom) is presented the result of the circulating current $i_{o}$. Notice that the control assures a circulating current approximately null and without oscillations. Choosing $\mu_{x}=0.5$ the task of controlling the circulating current is divided symmetrically between the GSC and the SGSC, similarly to the methodology used for dual inverters in [49], [58], [59], in which the task of reducing the circulating current is carried out by the two inverters. In fact, when $\mu_{x}=0.0$ or $\mu_{x}=1.0$, not only oscillations in the circulating current appear as the control and general stability of the system are impaired, since the circulating voltage is not more symmetrically compensated by the converters (GSC and SGSC). Therefore, in addition to the circulating current control loop is necessary to adjust $\mu_{x}=0.5$ to maintain the system stability and ensure null circulating current.

Figure 8.a shows the dc-link voltage is regulated by its reference voltage of $650 \mathrm{~V}$. At the inception of voltage sag, the dc-link voltage rises to approximately $652 \mathrm{~V}$. On the other hand, at the clearance of voltage sag, the dc-link voltage drops to approximately $648 \mathrm{~V}$. Thus, the control system regulates the dc-link voltage to the reference value during the grid voltage sag and the dc-link voltage does not exceed the limits $2 \%$ of reference value neither at the inception nor at the clearance of voltage sag. It is worth mentioning here that the dc-link inertia constant is approximately $29 \mathrm{~ms}$, a typical value for WECS [60] and approximately $6 \%$ of the grid fault duration. However, double-frequency oscillations appears in the dclink voltage during the grid sag due the voltage imbalances. Even though, these oscillations represents less than $1 \%$ of dclink voltage and they do not impair the system stability and performance.

Figure 8.b shows the result for active and reactive powers with transient oscillations. The stator active power is set to the reference value of $-1.5 \mathrm{~kW}$ even during voltage sag event. During the grid voltage sag, the system supplies 120 var of reactive power to the grid, according to the Brazilian grid 


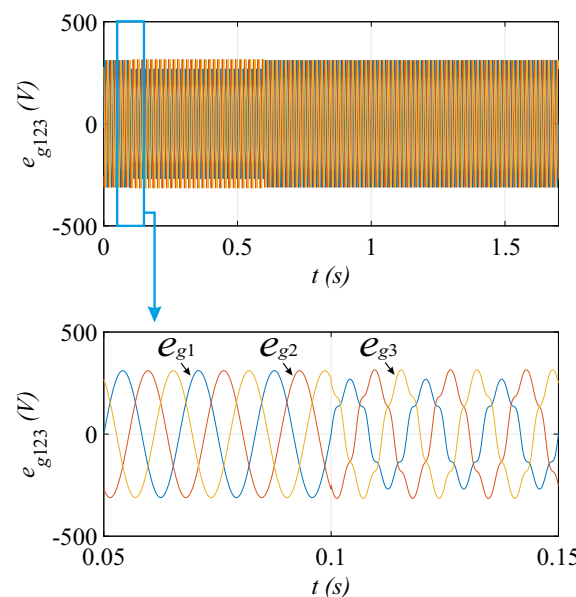

(a)

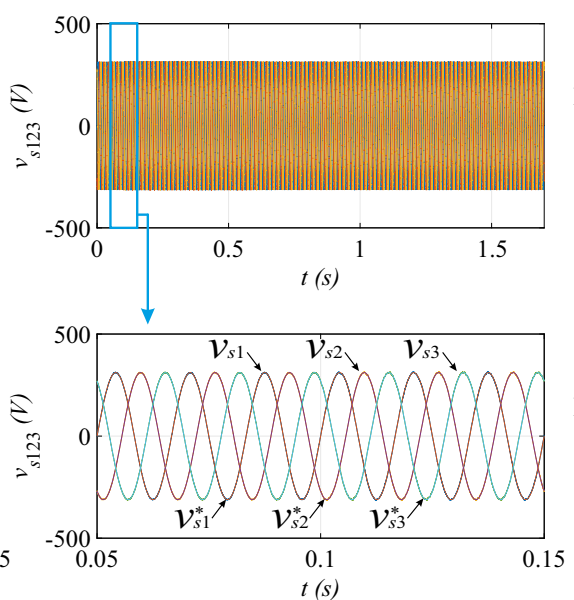

(b)

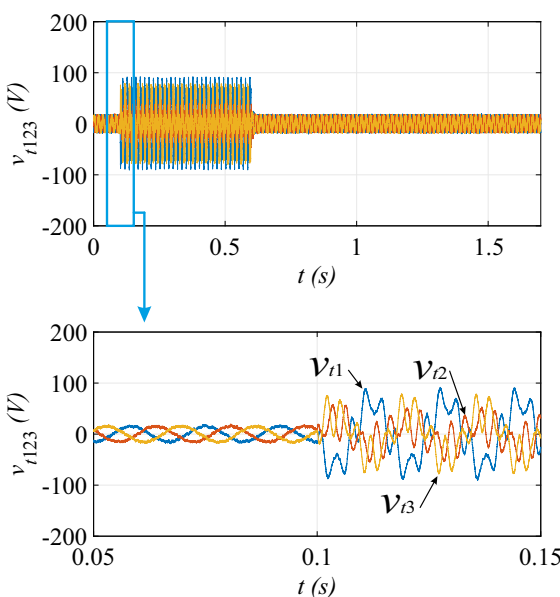

(c)

Fig. 6. Simulation results: (a) Grid voltages $\left(e_{g 1}, e_{g 2}\right.$, and $\left.e_{g 3}\right)$. (b) Stator voltages $\left(v_{s 1}, v_{s 2}\right.$, and $\left.v_{s 3}\right)$. (c) SGSC voltages $\left(v_{t 1}, v_{t 2}\right.$, and $\left.v_{t 3}\right)$.

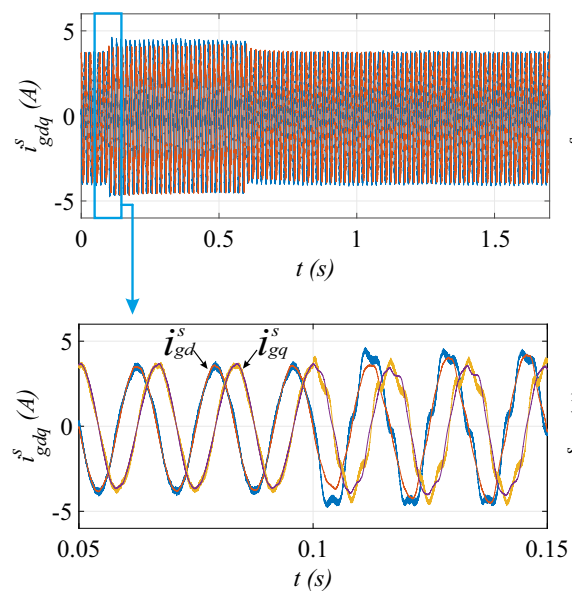

(a)
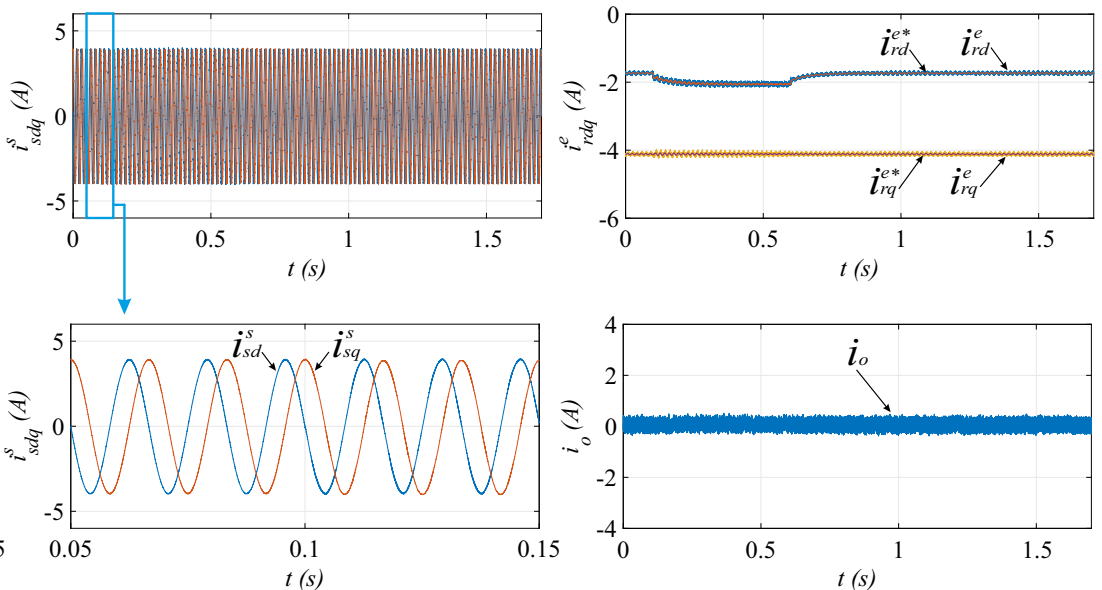

(b)

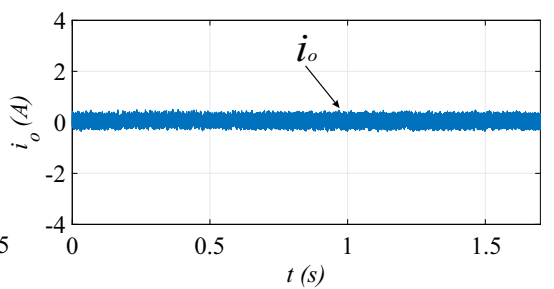

(c)

Fig. 7. Simulation results: (a) Grid currents in the stationary reference frame $\left(i_{g d}^{s}\right.$ and $i_{g q}^{s}$ ). (b) Stator currents in the stationary reference frame $\left(i_{s d}^{s}\right.$ and $\left.i_{s q}^{s}\right)$. (c) Top: $d q$-axis rotor currents in synchronous reference frame $\left(i_{r d}^{e d}\right.$ and $\left.i_{r q}^{e}\right)$; bottom: circulating current $\left(i_{o}\right)$.

connection code that requires injection of reactive currents into the grid when a voltage sag occurs [25]. Both the stator and grid reactive powers $\left(Q_{s}\right.$ and $\left.Q_{g}\right)$ are adjusted to this reference value during the fault [Figures 8.b and 8.c]. When the sag is cleared and the grid voltages are restored, the stator and grid reactive powers are set back to null values, resuming operation with a high power factor both in DFIG and in the grid. Both active and reactive powers do not present double-frequency oscillations even with the presence of the grid voltage imbalances. SGSC compensates for these disturbances and thus prevents these oscillations from occurring in the active and reactive powers of the stator. However, the same is not true for the grid reactive power, which presents double-frequency oscillations during the grid voltage sag, since the control employed at the GSC does not provide for the compensation of these disturbances.

\section{B. Three-Phase Voltage Sag}

Simulation results for a three-phase voltage sag are presented in Figures 9 to 11. For these results, a three-phase voltage sag of $80 \%$ of the rated voltage is applied at $t=0.1$ $\mathrm{s}$ and cleared after $0.5 \mathrm{~s}$, in accordance to the requirements presented in Figure 1. As for unbalanced conditions, the series converter ensures sinusoidal and compensated stator voltages despite the grid voltage sag [Figure 9.b]. The stator voltages is compensated with a reasonable dynamic response at the inception and at the clearance of the voltage sag. Also, the voltage of the SGSC rises to compensate the grid voltage sag, as shown in Figure 9.c.

Figure 10.a shows that the grid currents rises up to nearly $12 \mathrm{~A}$ at the moment of the sag inception. However, the control system bring the grid currents back to the pre-fault value in $0.15 \mathrm{~s}$, restoring the stability of the system. The stator currents are sinusoidal and do not present any value rise at the inception of voltage sag, since the series converters guarantees a smooth maintenance of the pre-fault conditions at the stator terminals [Figure 10.b].The $d q$-axes rotor currents in the synchronous reference frame are presented in Figure 10.c (top). Also for this three-phase voltage sag, the RSC control loop regulates the rotor currents to their respective reference 


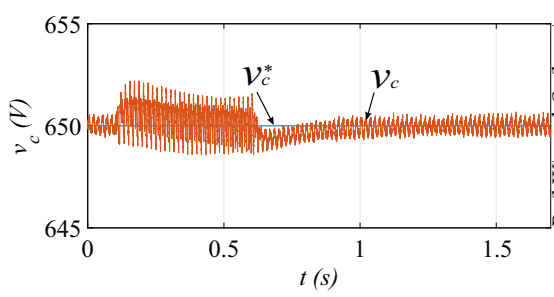

(a)

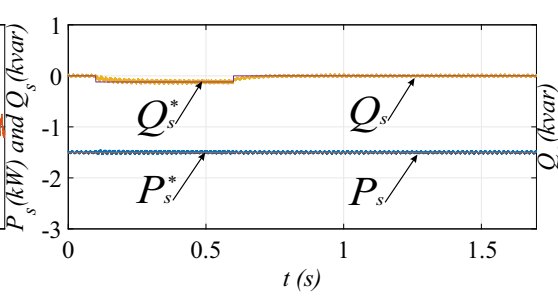

(b)

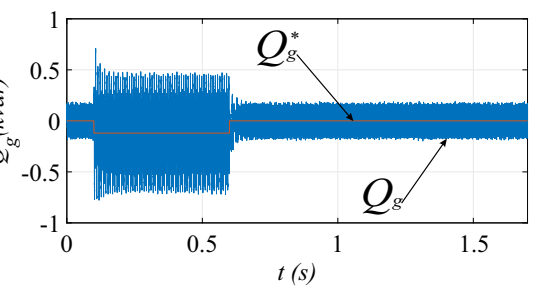

(c)

Fig. 8. Simulation results: (a) DC-link voltage $\left(v_{c}\right)$. (b) Stator active and reactive powers $\left(P_{s}\right.$ and $\left.Q_{s}\right)$. (c) Grid reactive power $\left(Q_{g}\right)$.

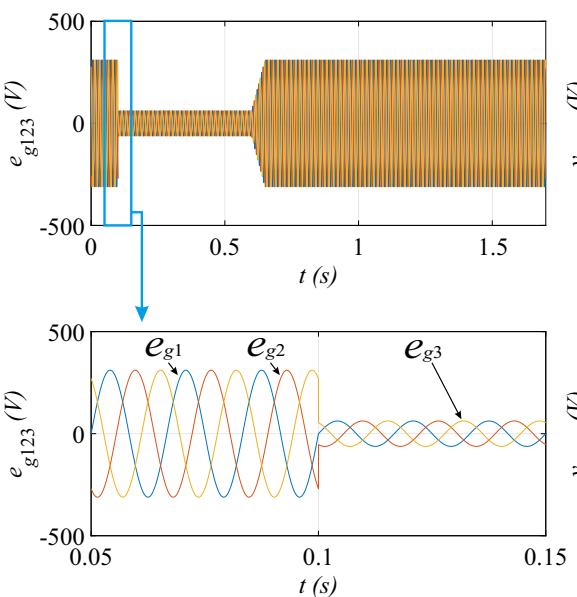

(a)

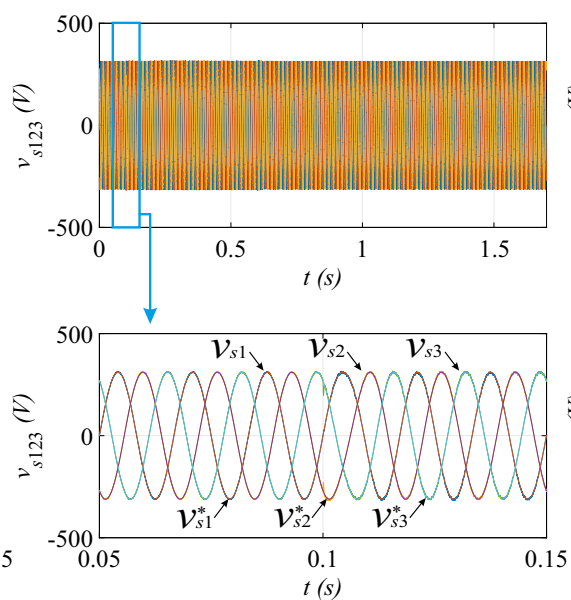

(b)

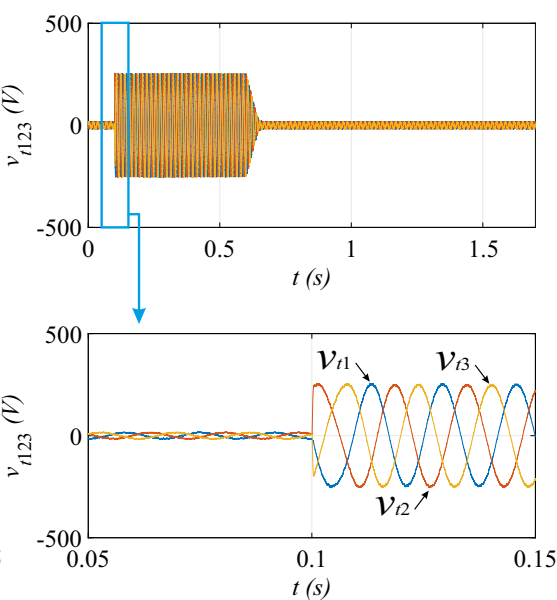

(c)

Fig. 9. Simulation results: (a) Grid voltages $\left(e_{g 1}, e_{g 2}\right.$, and $\left.e_{g 3}\right)$. (b) Stator voltages $\left(v_{s 1}, v_{s 2}\right.$, and $\left.v_{s 3}\right)$. (c) SGSC voltages $\left(v_{t 1}, v_{t 2}\right.$, and $\left.v_{t 3}\right)$.

value. As for unbalanced condition, the circulating current $i_{o}$ is approximately null and without oscillations [Figure 10.c (bottom)].

Figure 11.a shows that the dc-link voltage is regulated by its reference voltage of $650 \mathrm{~V}$ even for a three-phase voltage sag. At the inception and clearance of voltage sag, the dc-link voltage rises to approximately $660 \mathrm{~V}$. As for unbalanced grid voltages, the control system regulates the dc-link voltage to the reference value during the grid voltage sag and the dc-link voltage does not exceed the limits $2 \%$ of reference value, even with a inertia constant of $29 \mathrm{~ms}$.

According to the Brazilian grid connection code, during the grid voltage sag of $80 \%$, the system most supplies a 1 p.u. reactive current to the grid [25]. Thus, to meet the requirements of the grid code, both the stator and grid reactive powers $\left(Q_{s}\right.$ and $\left.Q_{g}\right)$ are adjusted to supplies 300 var during the grid voltage sag [Figures 11.b and 11.c]. To prevent high currents in the converters, the stator active power is reduced to zero, since the grid code does not require active power injection during these level of voltage sag [Figures 11.b]. When the sag is cleared and the grid voltages are restored, the stator and grid reactive powers are set back to null values and the stator active power returns to $-1.5 \mathrm{~kW}$, resuming the pre-fault operation.

Simulation results show the proposed system achieves the control objectives, ensuring a regulated dc-link voltage and sinusoidal and balanced voltages at the DFIG stator terminals, while the rotor side converter control ensures regulated stator active and reactive powers during a voltage sag event. Moreover, the proposed system also guarantees null circulating current between GSC and SGSC.

\section{EXPERIMENTAL RESULTS}

The proposed topology has been tested in the laboratory to validate the performance of the series grid side converter compensation, the DFIG control through the rotor side converter, and the GSC dc-link voltage regulation. A threephase autotransformer with voltage regulation is connected between the grid and the proposed topology. A dc machine was employed in the experiment as a primary machine to provide mechanical power to the DFIG (Figure 12). The switching frequency of the converters (GSC, RSC and SGSC) and the sampling frequency used in the experiment were 10 $\mathrm{kHz}$.

As shown in Figure 12, the experimental set-up is based on four sets of SEMIKRON manufacturer (based on IGBT SKM50GB123D switches), and a DSP TMS320F28335 with a microcomputer equipped with appropriate plug-in boards and sensors. The results were obtained using an Agilent oscilloscope model DSO 7034A $350 \mathrm{MHz}$.

A capacitor bank as dc-link with $2200 \mu \mathrm{F}$ and the GSC was connected to the grid through an inductive filter with 7 $\mathrm{mH}$. The parameters of the DFIG utilized in the experiment are presented in Table I.

Steady-state operation mode has been considered in the experimental tests. Experimental results are obtained for a three-phase grid voltage sag of $50 \%$, with a dc-link voltage 


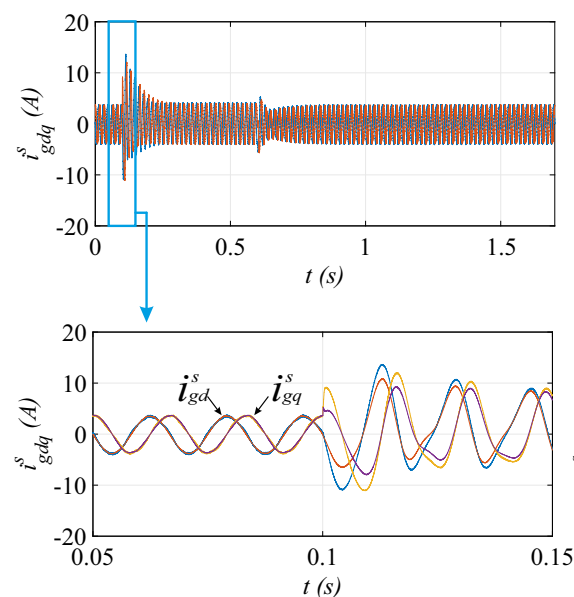

(a)

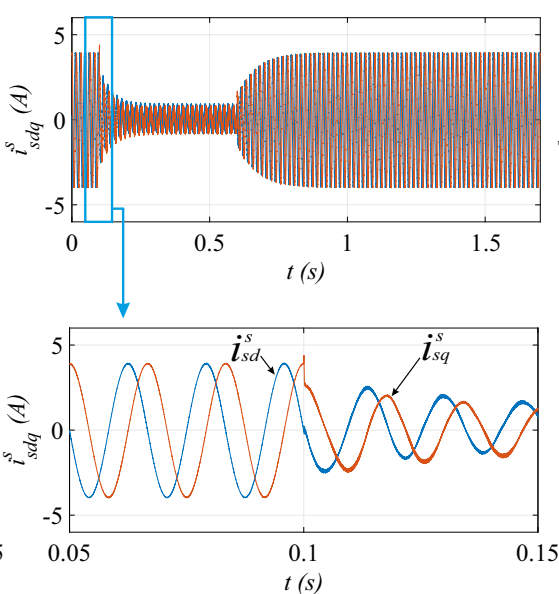

(b)
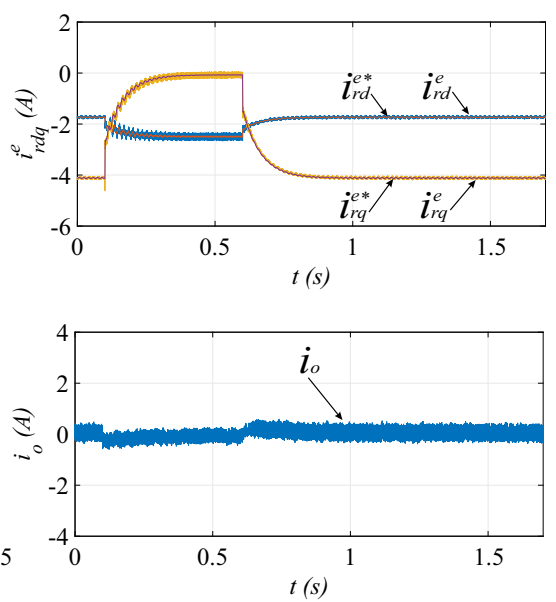

(c)

Fig. 10. Simulation results: (a) Grid currents in the stationary reference frame $\left(i_{g d}^{s}\right.$ and $\left.i_{g q}^{s}\right)$. (b) Stator currents in the stationary reference frame $\left(i_{s d}^{s}\right.$ and $i_{s q}^{s}$ ). (c) Top: $d q$-axis rotor currents in synchronous reference frame $\left(i_{r d}^{e}\right.$ and $\left.i_{r q}^{e}\right)$; bottom: circulating current $\left(i_{o}\right)$.

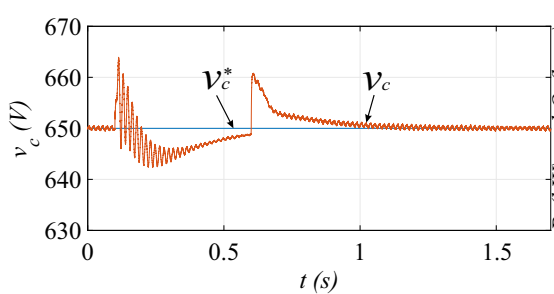

(a)

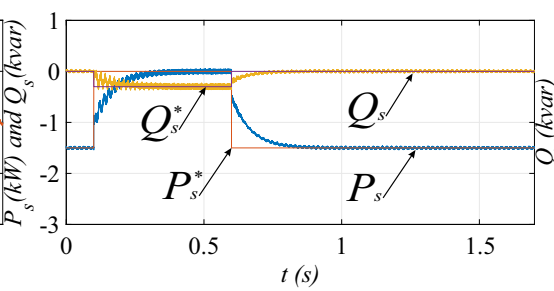

(b)

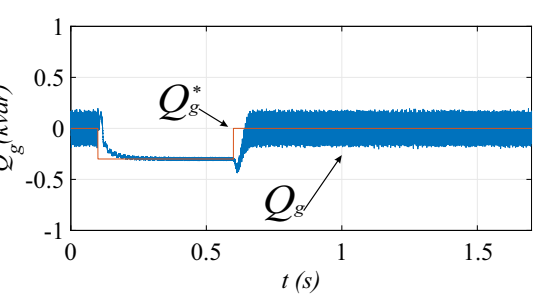

(c)

Fig. 11. Simulation results: (a) DC-link voltage $\left(v_{c}\right)$. (b) Stator active and reactive powers $\left(P_{s}\right.$ and $\left.Q_{s}\right)$. (c) Grid reactive power $\left(Q_{g}\right)$.

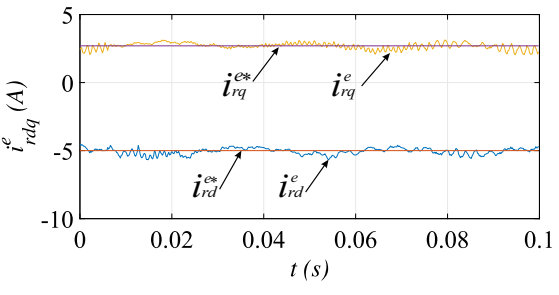

(a)

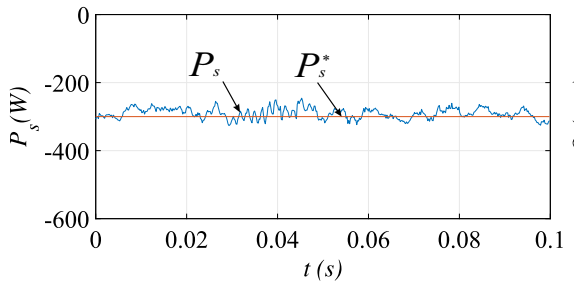

(b)

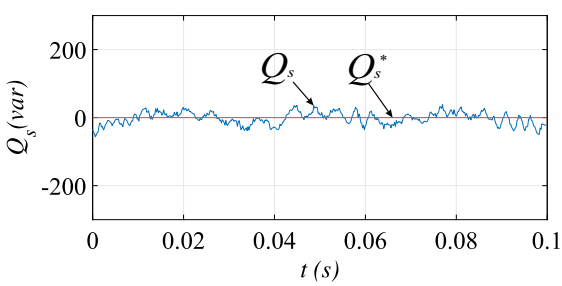

(c)

Fig. 15. Experimental results: (a) $d q$-axes rotor currents in the synchronous reference frame $\left(i_{r d}^{e}\right.$ and $\left.i_{r q}^{e}\right)$. (b) Stator active power $\left(P_{s}\right)$. (c) Stator reactive power $\left(Q_{s}\right)$.

of $325 \mathrm{~V}$, grid voltage (with sag) equal to $55 \mathrm{~V}$ rms (phase voltage), and reference stator voltage equal to $110 \mathrm{~V}$ rms (phase voltage). Decoupled stator active and reactive power controls were employed in the rotor side converter in order to validate the DFIG control capability. The rotor angle $\theta_{r}$ was obtained by an encoder coupled to the DFIG rotor shaft.

Figures 13 to 15 present the experimental results. In Figure 13.a, experimental results for grid and stator voltages are presented. The series grid side converter adjusts the stator voltages $\left(v_{s 1}\right.$ and $\left.v_{s 2}\right)$ back to the rating value of $110 \mathrm{~V}$ despite the grid voltage sag $\left(e_{g 1}\right.$ and $\left.e_{g 2}\right)$. The experimental results for stator voltages and currents are presented in Figure 13.b. The results show compensated and sinusoidal stator voltages with high power factor, since null reactive power is generated.

In Figure 14.a, experimental result for dc-link voltage is presented. It can be observed that the grid side converter control ensures a dc-link voltage $\left(v_{c}\right)$ approximately $325 \mathrm{~V}$. The result for circulating current $\left(i_{o}\right)$ is presented in Figure 14.b. It is noted that the GSC and SGSC control loops ensure approximately null circulating current even with grid voltage sag.

The experimental results presented in Figure 15 were obtained from the voltage and current sensor measuring by the DSP digital vectors. The results of the $d q$-axes rotor currents in the synchronous reference frame are presented in Figure 15.a. It is possible to notice that the rotor currents are regulated. Experimental results for DFIG stator active and reactive powers and their respective reference (i.e., 0 var for stator reactive power and $-300 \mathrm{~W}$ for stator active power) are shown in Figures 15.b and 15.c, respectively. It can be noticed that the rotor side converter ensures stator active power approximately equal to $-300 \mathrm{~W}$ and stator reactive power 


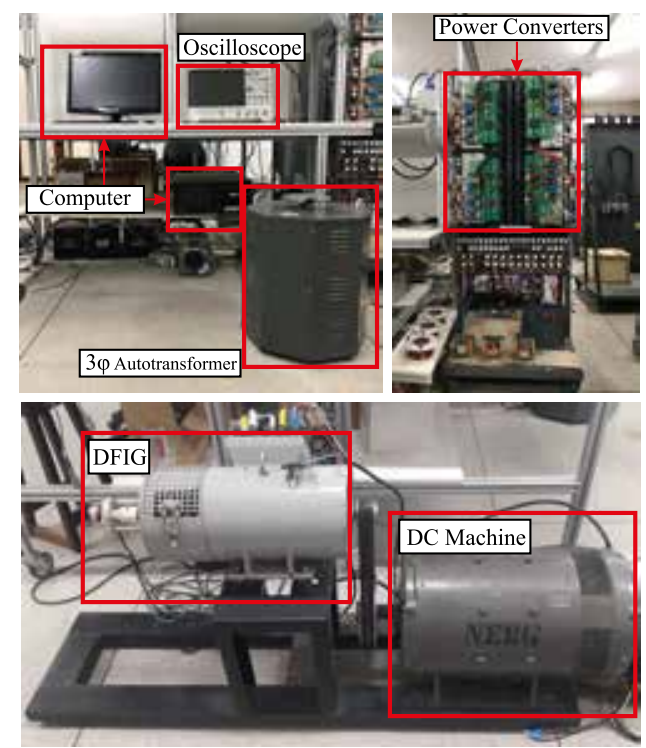

Fig. 12. Experimental set-up and DFIG/DC machine set.

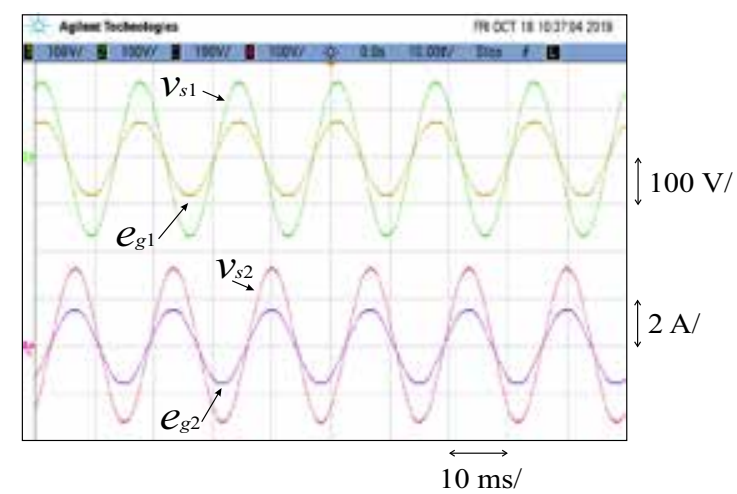

(a)

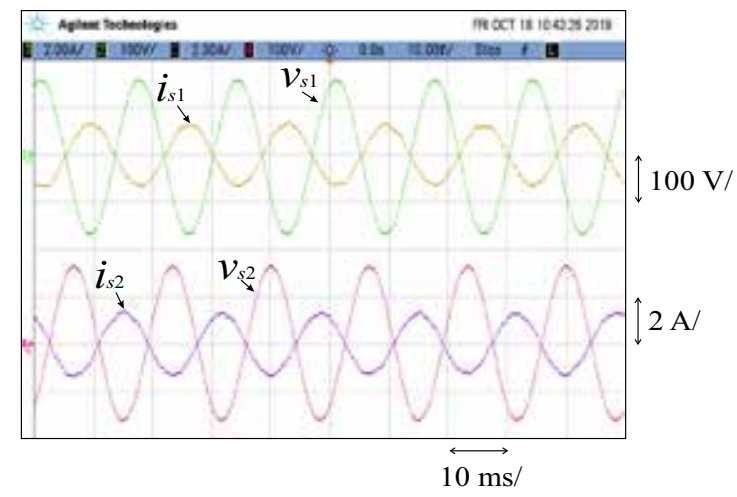

(b)

Fig. 13. Experimental results: (a) Grid and stator voltages $\left(e_{g 1}, e_{g 2}\right.$, $v_{s 1}$, and $\left.v_{s 2}\right)$. (b) Stator voltages and currents $\left(v_{s 1}, v_{s 2}, i_{s 1}\right.$, and $\left.i_{s 2}\right)$.

approximately null.

\section{CONCLUSIONS}

In this paper, a wind energy conversion system based on DFIG with additional series grid side converter connected without transformer was proposed and analyzed. The control of the proposed system is able to maintain balanced and sinusoidal voltages at DFIG stator terminals, thus eliminating the problems related to unbalanced grid voltages, such as

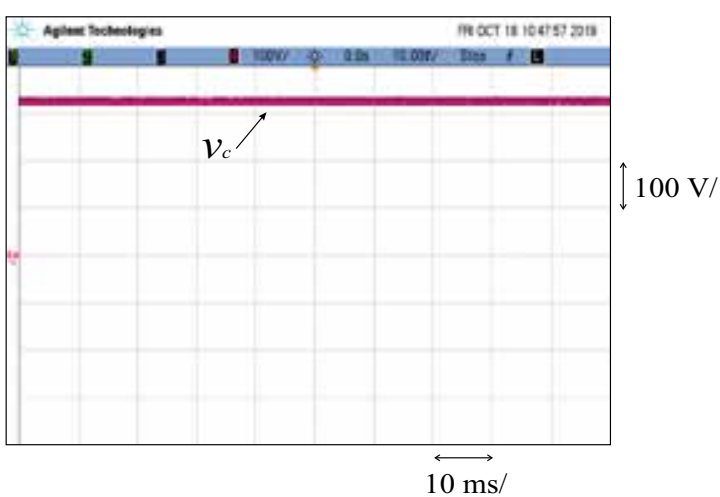

(a)

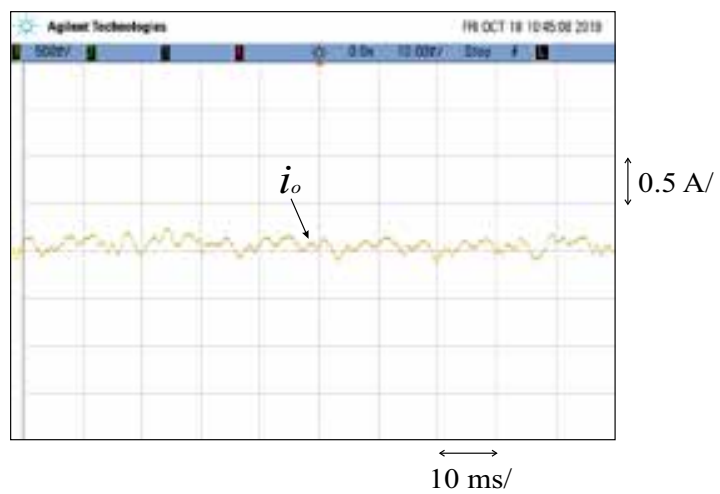

(b)

Fig. 14. Experimental results: (a) DC-link voltage $\left(v_{c}\right)$. (b) Circulating current $\left(i_{o}\right)$.

over-current in the rotor, over-voltage in the dc-link, doublefrequency oscillations in electromagnetic torque and stator power, and rotor over-speed. Moreover, the control strategy of the proposed system keeps null circulating current between the grid side converter and the series converter, avoiding the need for bulky components. During unbalanced grid voltage sags, the grid currents become unbalanced and distorted as well. However, future works could to explore a more robust control for GSC in order to compensate this disturbances in the grid currents. The proposed system with additional series grid side converter is a solution to improve the low voltage ridethrough capability of wind energy conversion system based on DFIG so that meets with grid code requirements.

\section{ACKNOWLEDGEMENTS}

The authors would like to thank $\mathrm{CNPq}$ for financial support.

\section{REFERENCES}

[1] A. Gomez-Expósito, A. J. Conejo, C. Cañizares, Eletric Energy Systems: Analysis and Operation, 1 ed., LTC, 2011.

[2] C. W. E. A. CWEA, WWEA Quarterly Bulletin Special Issue: World Wind Energy Report 2014, 1 ed., World Wind Energy Association - WWEA, 2015.

[3] S. V. Dias, T. R. F. Neto, L. L. N. Reis, B. C. Torrico, J. C. T. Campos, "Controlador de Corrente Preditivo Contínuo com Antiwindup Aplicado a um Sistema de Geração Eólico Baseado em DFIG”, Eletrônica de Poténcia, vol. 22, no. 1, pp. 71-80, jan./mar. 2017. 
[4] H. Polinder, F. F. A. van der Pijl, G.-J. de Vilder, P. Tavner, "Comparison of Direct-Drive and Geared Generator Concepts for Wind Turbines", IEEE Transactions on Energy Conversion, vol. 21, no. 3, pp. 725-233, Sep 2006.

[5] F. Blaabjerg, Z. Chen, S. B. Kjaer, "Power Electronics as Efficient Interface in Dispersed Power Generation Systems", IEEE Transactions on Power Electronics, vol. 19, no. 5, pp. 1184-1194, Sep. 2004.

[6] A. Sguarezi Filho, J. C. Cardoso, "Energia eólica: tipos de geradores e conversores usados atualmente", O Setor Elétrico - Espaço do IEEE, pp. 160 - 161, Maio 2014.

[7] H. Mohammadpour, S. G. Zadeh, S. Tohidi, "Symmetrical and asymmetrical low-voltage ride through of doubly-fed induction generator wind turbines using gate controlled series capacitor", IET Renewable Power Generation, vol. 9, no. 7, pp. 840-846, Aug. 2015.

[8] H. Nian, Y. Song, P. Zhou, Y. He, "Improved Direct Power Control of a Wind Turbine Driven Doubly Fed Induction Generator During Transient Grid Voltage Unbalance", IEEE Trans Energy Convers, vol. 26, no. 3, pp. 976-986, March 2011.

[9] G. Abad, M. A. RodrÃguez, G. Iwanski, J. Poza, "Direct Power Control of Double-Fed-InductionGenerator-Based Wind Turbines Under Unbalanced Grid Voltage", IEEE Trans Power Electronics, vol. 25, no. 2, pp. 442-452, Feb. 2010.

[10] A. J. S. Filho, A. L. F. Murari, C. E. Capovilla, J. A. Altuna, R. V. Jacomini, "A State Feedback DFIG Power Control for Wind Generation", Eletrônica de Poténcia, vol. 20, no. 2, pp. 151-159, mar./mai. 2015.

[11] O. Abdel-Baqi, A. Nasiri, "Series Voltage Compensation for DFIG Wind Turbine Low-Voltage Ride-Through Solution", IEEE Transactions on Energy Conversion, vol. 26, no. 1, pp. 272-280, Jan. 2011.

[12] H. Xu, J. Hu, Y. He, "Operation of Wind-TurbineDriven DFIG Systems Under Distorted Grid Voltage Conditions: Analysis and Experimental Validations", IEEE Transactions on Power Electronics, vol. 27, no. 5, pp. 2354-2366, May 2012.

[13] J. Yao, H. Li, Z. Chen, X. Xia, X. Chen, Q. Li, Y. Liao, "Enhanced Control of a DFIG-Based Wind-Power Generation System With Series Grid-Side Converter Under Unbalanced Grid Voltage Conditions", IEEE Trans Power Electron, vol. 28, no. 7, pp. 3167-3181, Sep 2013.

[14] F. K. A. Lima, C. G. C. Branco, "Modelo em Malha Fechada para o Gerador de Indução Duplamente Alimentado Baseado em Controladores Proporcional e Integral", Eletrônica de Poténcia, vol. 21, no. 2, pp. 81-90, mar./jun. 2016.

[15] P. S. Flannery, G. Venkataramanan, "A Fault Tolerant Doubly Fed Induction Generator Wind Turbine Using a Parallel Grid Side Rectifier and Series Grid Side Converter", IEEE Transactions on Power Electronics, vol. 23, no. 3, May 2008, doi: 10.1109/TPEL.2008.921179.
[16] S. Omar, A. Helal, I. Elarabawy, "Stator voltage sensorless DFIG with low voltage ride-through capability using series and parallel grid side converters", in 2016 7th International Renewable Energy Congress (IREC), pp. 1-6, Mar. 2016.

[17] P. S. Flannery, G. Venkataramanan, "Unbalanced Voltage Sag Ride-Through of a Doubly Fed Induction Generator Wind Turbine With Series Grid-Side Converter", IEEE Transactions on Industry Applications, vol. 45, no. 5, pp. 1879-1887, Sep. 2009, doi:10.1109/TIA.2009.2027540.

[18] C. Zhan, C. D. Barker, "Fault ride-through capability investigation of a doubly-fed induction generator with an additional series-connected voltage source converter", in The 8th IEE International Conference on AC and DC Power Transmission, pp. 79-84, Mar. 2006.

[19] F. K. A. Lima, E. H. Watanabe, P. Rodríguez, A. Luna, "Controle de Gerador de Indução Duplamente Alimentado Diante de Afundamentos de Tensão", Eletrônica de Poténcia, vol. 14, no. 3, pp. 189-199, ago. 2009.

[20] P. S. Flannery, G. Venkataramanan, "Evaluation of Voltage Sag Ride-Through of a Doubly Fed Induction Generator Wind Turbine with Series Grid Side Converter", in 2007 IEEE Power Electronics Specialists Conference, pp. 1839-1845, June 2007, doi:10.1109/PESC.2007.4342281.

[21] Y. Boukhris, A. E. Makrini, H. E. Moussaoui, H. E. Markhi, "High voltage ride-through capability using series grid side converter for doubly fed induction generator based wind turbines", in $20153 \mathrm{rd}$ IRSEC, Dec 2015, doi:10.1109/IRSEC.2015.7454961.

[22] M. Bahramipanah, G. Farivar, S. Afsharnia, "DFIG wind turbine three single phase grid side converters strategy control", in 2012 3rd Power Electronics and Drive Systems Technology (PEDSTC), pp. 336-341, Feb. 2012.

[23] O. Abdel-Baqi, A. Esmaili, A. Nasiri, "Digital control of three-phase series converter for DFIG wind turbine low voltage ride-through solution", in 2011 Twenty-Sixth Annual IEEE Applied Power Electronics Conference and Exposition (APEC), pp. 946-951, Mar. 2011.

[24] K. E. Okedu, "Enhancing DFIG wind turbine during three-phase fault using parallel interleaved converters and dynamic resistor", IET Renewable Power Generation, vol. 10, no. 8, pp. 1211-1219, Sep. 2016.

[25] O. N. do Sistema, Submódulo 2.10 - Requisitos técnicos mínimos para a conexão ás instalações de transmissão, 1 ed., ONS, 2020.

[26] A. M. A. Haidar, M. K. M., M. T. Hagh, "A Coordinated Control Approach for DC link and Rotor Crowbars to Improve Fault Ride-Through of DFIGBased Wind Turbine", IEEE Trans Indus Appl, vol. 53, no. 4, pp. 4073-4086, Mar. 2017.

[27] P. Cheng, H. Nian, "Collaborative Control of DFIG System During Network Unbalance Using ReducedOrder Generalized Integrators", IEEE Transactions on 
Energy Conversion, vol. 30, no. 2, pp. 453 - 464, June 2015.

[28] J.-I. Jang, Y.-S. Kim, D.-C. Lee, "Active and Reactive Power Control of DFIG for Wind Energy Conversion under Unbalanced Grid Voltage", in Power Electronics and Motion Control Conference, 2006, vol. 3, pp. 1-5, Shanghai, China, Aug. 2006, iPEMC 2006. CES/IEEE 5th International.

[29] S. Seman, J. Niiranen, S. Kanerva, A. Arkkio, J. Saitz, "Performance Study of a Doubly Fed Wind-power Induction Generator under Network Disturbances", IEEE Trans Energy Conversion, vol. 21, no. 4, pp. 883 - 890, Dec. 2006.

[30] S. Seman, J. Niiranen, A. Arkkio, "Ride-Through Analysis of Doubly Fed Induction Wind-Power Generator Under Unsymmetrical Network Disturbance", IEEE Transactions on Power Systems, vol. 21 , no. 4, pp. 1782 - 1789, Nov. 2006.

[31] A. O. Ibrahim, T. H. Nguyen, D. Lee, S. Kim, "A Fault Ride-Through Technique of DFIG Wind Turbine Systems Using Dynamic Voltage Restorers", IEEE Transactions on Energy Conversion, vol. 26, no. 3, pp. 871-882, Sep. 2011, doi:10.1109/TEC.2011.2158102.

[32] J. Hu, Y. He, "Modeling and enhanced control of DFIG under unbalanced grid voltage conditions", ELSEVIER Electric Power System Research, vol. 79, no. 2, pp. 273-281, Feb. 2009.

[33] Í. A. C. de Oliveira, N. Rocha, E. R. C. da Silva, C. B. Jacobina, I. S. de Freitas, "A stationary stator reference frame control of DFIG under unbalanced voltage conditions", in 2015 IEEE 13th Brazilian Power Electronics Conference and 1st Southern Power Electronics Conference (COBEP/SPEC), pp. 1-6, Nov 2015, doi:10.1109/COBEP.2015.7420044.

[34] V. F. Mendes, H. Pereira, F. F. Matos, W. Hofmann, S. R. Silva, "Doubly-fed induction generator control during unbalanced grid conditions", in Power Electronics Conference and 1st Southern Power Electronics Conference (COBEP/SPEC), Feb. 2016, 2015 IEEE 13th Brazilian.

[35] Y. Liao, H. Li, J. Yao, K. Zhuang, "Operation and control of a grid-connected DFIG-based wind turbine with series grid-side converter during network unbalance", ELSEVIER Electric Power Systems Research, vol. 81, no. 1, pp. 228 - 236, Sep 2011.

[36] A. Luna, K. Lima, F. Corcoles, E. Watanabe, P. Rodriguez, R. Teodorescu, "Control of DFIGWT under unbalanced grid voltage conditions", in 2009 IEEE Energy Conversion Congress and Exposition, pp. 370-377, Sep. 2009, doi: 10.1109/ECCE.2009.5316125.

[37] H. Xu, J. Hu, Y. He, "Integrated Modeling and Enhanced Control of DFIG Under Unbalanced and Distorted Grid Voltage Conditions", IEEE Transactions on Energy Conversion, vol. 27, no. 3, pp. 725-736, Sep. 2012, doi:10.1109/TEC.2012.2199495.

[38] M. E. Zarei, B. Asaei, "Predictive direct torque control of DFIG under unbalanced and distorted stator voltage conditions", in 2013 12th International Conference on
Environment and Electrical Engineering, pp. 507-512, May 2013, doi:10.1109/EEEIC.2013.6549568.

[39] N. N. Joshi, N. Mohan, "New Scheme to Connect DFIG to Power Grid", in IECON 2006 - 32nd Annual Conference on IEEE Industrial Electronics, pp. 42254230, Sep/Oct 2006.

[40] J. R. Massing, H. Pinheiro, "Design and control of doubly-fed induction generators with series grid-side converter", in 2008 34th Annual Conference of IEEE Industrial Electronics, pp. 139-145, Nov. 2008.

[41] V. P. Suppioni, A. P. Grilo, J. C. Teixeira, "Methodology for grid voltage unbalance compensation appling a two-converter series DFIG topology", in 2015 IEEE 15th International Conference on Environment and Electrical Engineering (EEEIC), pp. 1736-1741, Jul. 2015, doi:10.1109/EEEIC.2015.7165434.

[42] B. Jahanbakhsh, D. Xu, "Improved low voltage ride through capability of doubly fed induction generator using series grid side converter", in Proceedings of The 7th International Power Electronics and Motion Control Conference, pp. 2207-2211, Jun. 2012.

[43] Z. Din, J. Zhang, J. Zhao, Y. Jiang, "Doubly Fed Induction Generator with Cascade Converter for Improving Dynamic Performances", in 2018 IEEE Energy Conversion Congress and Exposition (ECCE), pp. 2568-2575, Sep. 2018, doi:10.1109/ECCE.2018.8558069.

[44] I. A. C. de Oliveira, C. B. Jacobina, N. Rocha, P. L. S. Rodrigues, "Wind Energy Conversion System Based on DFIG with Three-Phase Series Active Filter Operating with Floating Capacitors", in 2018 IEEE Energy Conversion Congress and Exposition (ECCE), pp. 5500-5507, Sep. 2018, doi: 10.1109/ECCE.2018.8558422.

[45] A. Javadi, H. F. Blanchette, K. Al-Haddad, "A novel transformerless hybrid series active filter", in IECON 2012 - 38th Annual Conference on IEEE Industrial Electronics Society, pp. 5312-5317, Oct. 2012.

[46] I. A. C. Oliveira, N. Rocha, E. R. C. Silva, L. M. S. Siqueira, E. C. Menezes, C. B. Jacobina, "Wind energy conversion system based on DFIG with series grid side converter without transformer", in Energy Conversion Congress and Exposition (ECCE), 2017 IEEE, pp. 3281-3288, Oct. 2017.

[47] I. A. C. de Oliveira, C. B. Jacobina, N. Rocha, P. L. S. Rodrigues, "Wind Energy Conversion System Based On DFIG With Three-Phase Series Active Filter And Single DC-Link", in 2018 IEEE Energy Conversion Congress and Exposition (ECCE), pp. 4544-4551, Sep. 2018, doi:10.1109/ECCE.2018.8558028.

[48] J. Holtz, X. Qi, "Optimal Control of Medium Voltage Drives An Overview", IEEE Transactions on Industrial Electronics, vol. 60, no. 12, pp. 5472-5481, Dec. 2013.

[49] D. Wu, X. Wu, L. Su, X. Yuan, J. Xu, "A Dual ThreeLevel Inverter-Based Open-End Winding Induction Motor Drive With Averaged Zero-Sequence Voltage Elimination and Neutral-Point Voltage Balance", IEEE 
Transactions on Industrial Electronics, vol. 63, no. 8, pp. 4783-4795, Aug. 2016.

[50] J. Yao, H. Li, Z. Chen, X. Xia, X. Chen, Q. Li, Y. Liao, "Enhanced Control of a DFIG-Based Wind-Power Generation System With Series Grid-Side Converter Under Unbalanced Grid Voltage Conditions", IEEE Trans Power Electron, vol. 28, no. 7, pp. 3167-3181, July 2013.

[51] H. Qi, Y. Wu, Y. Bi, "The main parameters design based on three-phase voltage source PWM rectifier of voltage oriented control", in 2014 International Conference on Information Science, Electronics and Electrical Engineering, vol. 1, pp. 10-13, April 2014, doi:10.1109/InfoSEEE.2014.6948057.

[52] M. K. Bourdoulis, A. T. Alexandridis, "Nonlinear stability analysis of DFIG wind generators in voltage oriented control operation", in 2013 European Control Conference (ECC), pp. 484-489, July 2013, doi: 10.23919/ECC.2013.6669692.

[53] O. Anaya-Lara, D. Campos-Gaona, E. L. MorenoGoytia, G. P. Adam, Offshore wind energy generation : control, protection, and integration to electrical systems, 1 ed., Wiley, 2014.

[54] P. Rodriguez, R. Teodorescu, I. Candela, A. V. Timbus, M. Liserre, F. Blaabjerg, "New Positive-sequence Voltage Detector for Grid Synchronization of Power Converters under Faulty Grid Conditions", in Power Electronics Specialists Conference (PESC), pp. 1 - 7, Jun. 2006, pESC '06. 37th IEEE.

[55] C. B. Jacobina, M. B. R. Correa, R. F. Pinheiro, E. R. C. Silva, "Modeling and Control of Unbalanced Three-phase Systems containing PWM Converters", in Industry Applications Conference, 1999. Thirty-Fourth IAS Annual Meeting, vol. 4, pp. 2173 - 2179, Phoenix, Az, USA, Oct. 1999, conference Record of the 1999 IEEE.

[56] C. Zou, B. Liu, S. Duan, R. Li, "Stationary Frame Equivalent Model of Proportional-Integral Controller in dq Synchronous Frame", IEEE Trans Power Electron, vol. 29, no. 9, pp. 4461-4465, Sep. 2014.

[57] M. H. J. Bollen, G. Olguin, M. Martins, "Voltage Dips at the Terminals of Wind Power Installations", Nordic Wind Power Conference, Mar 2004.

[58] H. Kubo, Y. Yamamoto, T. Kondo, K. Rajashekara, B. Zhu, "Zero-sequence current suppression for openend winding induction motor drive with resonant controller", in IEEE Applied Power Electronics
Conference and Exposition, pp. 2788-2793, Mar. 2016, aPEC 2016.

[59] J. Korhonen, J. Honkanen, T. J. KÃrkkÃinen, J. Nerg, P. Silventoinen, "Modulation and control methods to reduce zero sequence current in open-end winding motors", in IEEE International Electric Machines and Drives Conference, pp. 1-6, May 2017, iEMDC 2017.

[60] M. H. Rashid, Power Electronics Handbook: Devices, Circuits, and Applications., 1 ed., ButterworthHeinemann, 2011.

\section{BIOGRAPHIES}

Ítalo A. Cavalcanti de Oliveira, born in Paulista, Pernambuco, Brazil, in 1989. He received the B.S. and M.S. degrees in electrical engineering from the Federal University of Paraíba, João Pessoa, Brazil, in 2015 and 2017, respectively. He is currently working toward the $\mathrm{Ph} . \mathrm{D}$. degree in electrical engineering from Federal University of Campina Grande, Campina Grande. His research interests include energy system optimization, power electronics, and renewable energy, especially wind energy conversion systems.

Cursino Brandão Jacobina, born in Correntes, Brazil, in 1955. He received the B.S. degree in electrical engineering from the Federal University of Paraíba, Campina Grande, Brazil, in 1978, and the Diplôme d'Etudes Approfondies and the Ph.D. degrees in electrical engineering from the Institut National Polytechnique de Toulouse, Toulouse, France, in 1980 and 1983, respectively. From 1978 to March 2002, he was with the Department of Electrical Engineering, Federal University of Paraíba, João Pessoa, Brazil. Since April 2002, he has been with the Department of Electrical Engineering, Federal University of Campina Grande, Campina Grande, Brazil, where he is currently a Professor of Electrical Engineering. His research interests include electrical drives, power electronics and energy systems.

Nady Rocha, born in São Gabriel, Bahia, Brazil, in 1982. He received the B.S., M.S., and Ph.D. degrees in electrical engineering from the Federal University of Campina Grande, Campina Grande, Brazil, in 2006, 2008, and 2010, respectively. Since 2011, he has been with the Department of Electrical Engineering, Federal University of Paraíba, João Pessoa, where he is currently an Associate Professor of Electrical Engineering. His research interests include power electronics, renewable energy sources and electrical drives. 